\title{
A sensitive nonenzymatic hydrogen peroxide sensor based on $\mathrm{Fe}_{3} \mathrm{O}_{4}-\mathrm{Fe}_{2} \mathrm{O}_{3}$ nanocomposites
}

\author{
GUANG SHENG CAO*, PEILONG WANG, XIN LI, YUE WANG, GUILONG WANG \\ and JUNPING LI
}

Key Laboratory of Enhanced Oil \& Gas Recovery of Ministry of Education, Northeast Petroleum University, Daqing 163318, PR China

MS received 31 January 2014; revised 12 April 2014

\begin{abstract}
The $\mathrm{Fe}_{3} \mathrm{O}_{4}-\mathrm{Fe}_{2} \mathrm{O}_{3}$ nanocomposites were prepared by the co-precipitation method and followed by calcination process. The products were synthesized and characterized by X-ray diffraction, scanning electron microscopy, transmission electron microscopy and energy-dispersive X-ray analysis. The obtained $\mathrm{Fe}_{3} \mathrm{O}_{4}-\mathrm{Fe}_{2} \mathrm{O}_{3}$ nanocomposites were then applied to study the electrocatalytic reduction of hydrogen peroxide $\left(\mathrm{H}_{2} \mathrm{O}_{2}\right)$ in $0.01 \mathrm{M}$ pH 7.0 phosphate buffer medium. Then the $\mathrm{Fe}_{3} \mathrm{O}_{4}-\mathrm{Fe}_{2} \mathrm{O}_{3}$ nanocomposites were used as active electrode material of electrochemical sensors for $\mathrm{H}_{2} \mathrm{O}_{2}$ detection The detection sensitivity of the sensor was $20.325 \mu \mathrm{A} \mathrm{mM}^{-1}$, and the detection limit was estimated to be about $0.2 \mathrm{mM}$.
\end{abstract}

Keywords. $\mathrm{Fe}_{3} \mathrm{O}_{4} ; \mathrm{Fe}_{2} \mathrm{O}_{3}$; nanocomposites; hydrogen peroxide; sensor.

\section{Introduction}

Owing to its strong oxidizing property, hydrogen peroxide $\left(\mathrm{H}_{2} \mathrm{O}_{2}\right)$ is widely used in many fields. For example, $\mathrm{H}_{2} \mathrm{O}_{2}$ is useful for food production, sterilization, clinical applications and environmental analyses. ${ }^{1-4}$ Further, $\mathrm{H}_{2} \mathrm{O}_{2}$ has emerged as an important by-product of enzymatic reactions in the field of biosensing. Thus, accurate and reliable determination of $\mathrm{H}_{2} \mathrm{O}_{2}$ has been widely investigated using spectrometry, chemiluminescence and electrochemistry technologies. ${ }^{5-7}$ Among these methods, electrochemical method has been extensively applied due to its simple, accurate and fast analytical process. Many enzyme-based electrochemical biosensors towards $\mathrm{H}_{2} \mathrm{O}_{2}$ reduction have been made. However, the immobilized enzyme/protein on the surface of the electrode is facilitated to denature, which leads to such modified electrodes that suffer from a poor enzyme/protein activity, a low reproducibility and stability. ${ }^{8}$ Nanomaterials can play an important role in improving sensor performance, due to their large specific surface areas, excellent conductivities and compatibilities. In recent years, nanomaterials have been regarded as excellent substitutes for enzymes. Single crystal and vertically aligned $\mathrm{Co}_{3} \mathrm{O}_{4}$ nanowalls were synthesized, and the $\mathrm{Co}_{3} \mathrm{O}_{4}$ nanowall electrode was applied for the amperometric detection of $\mathrm{H}_{2} \mathrm{O}_{2}$ and showed a fast response and high sensitivity. ${ }^{9} \mathrm{Gu}$ et $a l^{10}$ have synthesized $\mathrm{Cu}-$ $\mathrm{Ni}(\mathrm{OH})_{2}$ nanocomposites and applied it as the fast and sensitive $\mathrm{H}_{2} \mathrm{O}_{2}$ sensor material. Ag nanoparticles were

\footnotetext{
*Author for correspondence (daqingcgs@ 163.com)
}

synthesized on indium tin oxide conducting glass substrate using the electrochemical deposition method, and the developed Ag nanoparticles sensor had excellent electrocatalytic activity for $\mathrm{H}_{2} \mathrm{O}_{2}$ detection. ${ }^{11}$ The electrocatalytic activity of $\mathrm{CuO}$ flower-like nanostructured electrode was investigated in terms of its application to enzymeless amperometric $\mathrm{H}_{2} \mathrm{O}_{2}$ sensors. $^{12}$

Transition metal oxide nanomaterials are one of the promising candidates for the active electrode material of non-enzymatic electrochemical sensors. Magnetite $\left(\mathrm{Fe}_{3} \mathrm{O}_{4}\right)$, which is chemically stable, non-toxic and non-carcinogenic, has a high magnetic saturation value. ${ }^{13-15}$ Hematite $(\alpha-$ $\mathrm{Fe}_{2} \mathrm{O}_{3}$ ), the most stable iron oxide under ambient condition with low-cost, non-toxicity and environmental-friendly features, is of great scientific and technology importance. ${ }^{16}$ $\mathrm{Fe}_{3} \mathrm{O}_{4}$ and $\mathrm{Fe}_{2} \mathrm{O}_{3}$ have been widely fabricated as gas sensor because of its good stability, lower cost and easy availability. Yu et $a l^{17}$ reported the application of chitosan- $\mathrm{Fe}_{3} \mathrm{O}_{4}$ nanocomposite-modified glassy carbon electrodes for the amperometric determination of bisphenol A. A novel imprinted sol-gel electrochemical sensor based on multi-walled carbon nanotubes doped with chitosan film on a carbon electrode has been developed. ${ }^{18}$ La-doped $\mathrm{Fe}_{2} \mathrm{O}_{3}$ nanotubes are synthesized by an electrospinning method and followed by calcination, and the nanotubesshow a good selectivity to acetone. ${ }^{19}$ To the best of our knowledge, $\mathrm{H}_{2} \mathrm{O}_{2}$ electrochemical sensor based on the $\mathrm{Fe}_{3} \mathrm{O}_{4}-\mathrm{Fe}_{2} \mathrm{O}_{3}$ nanocomposites has never been reported before. In this study, $\mathrm{Fe}_{3} \mathrm{O}_{4}-\mathrm{Fe}_{2} \mathrm{O}_{3}$ nanocomposites are synthesized by the co-precipitation method and followed by calcination process. The $\mathrm{Fe}_{3} \mathrm{O}_{4}-\mathrm{Fe}_{2} \mathrm{O}_{3}$ nanocomposites 
were applied for the sensitive amperometric detection of $\mathrm{H}_{2} \mathrm{O}_{2}$. The proposed sensor possesses high sensitivity and high stability.

\section{Experimental}

\subsection{Sample preparation}

$\mathrm{Fe}_{3} \mathrm{O}_{4}-\mathrm{Fe}_{2} \mathrm{O}_{3}$ nanocomposites were synthesized by the coprecipitation method and followed by calcination. Typically, $2.2 \mathrm{~g}$ of $\mathrm{FeCl}_{3} \cdot 6 \mathrm{H}_{2} \mathrm{O}$ and $2.3 \mathrm{~g}$ of $\mathrm{FeSO}_{4} \cdot 7 \mathrm{H}_{2} \mathrm{O}$ were dissolved in $30 \mathrm{ml}$ of $0.01 \mathrm{M} \mathrm{HCl}$ to form a transparent solution. When the solution became clear, the mixture was then added drop-wise to $40 \mathrm{ml}$ of $3 \mathrm{M} \mathrm{NH}_{3} \cdot \mathrm{H}_{2} \mathrm{O}$ with the reaction mixture vigorously stirred at $80^{\circ} \mathrm{C}$ for $150 \mathrm{~min}$. The final products were collected, followed by calcination at $350-500^{\circ} \mathrm{C}$ for $4 \mathrm{~h}$.

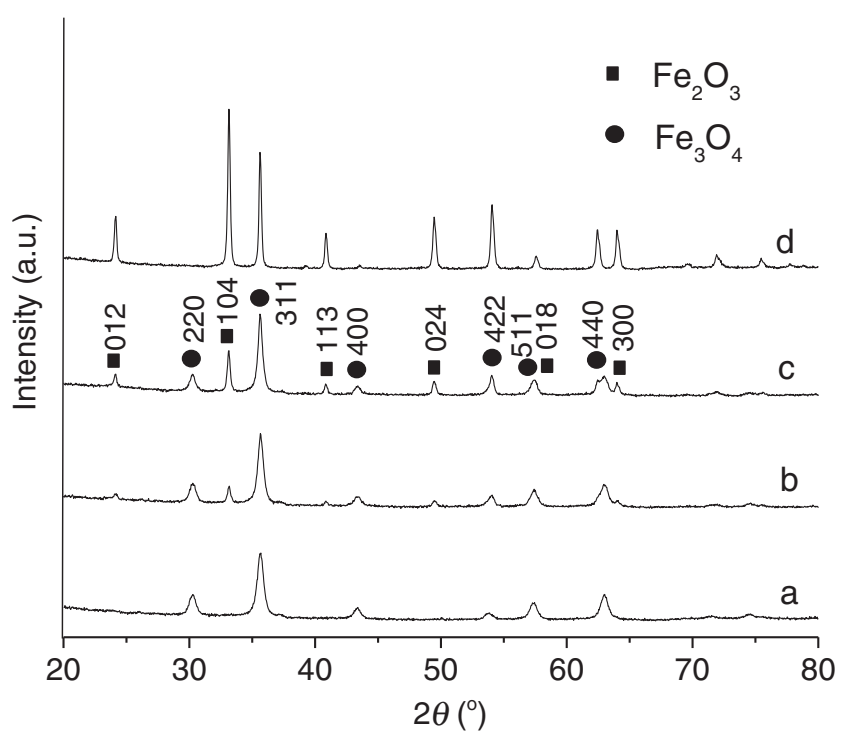

Figure 1. XRD patterns of products synthesized at different calcination temperatures: (a) $350^{\circ} \mathrm{C}$, (b) $400^{\circ} \mathrm{C}$, (c) $450^{\circ} \mathrm{C}$ and (d) $500^{\circ} \mathrm{C}$

\subsection{Electrode preparation}

Glassy carbon (GC) disks were polished with $0.03 \mathrm{~mm}$ $\mathrm{Al}_{2} \mathrm{O}_{3}$ powders. A typical suspension of the $\mathrm{Fe}_{3} \mathrm{O}_{4}-\mathrm{Fe}_{2} \mathrm{O}_{3}$ nanocomposites was prepared by suspending $6 \mathrm{mg} \mathrm{Fe}_{3} \mathrm{O}_{4}-$ $\mathrm{Fe}_{2} \mathrm{O}_{3}$ nanocomposites in $3 \mathrm{ml} 0.5 \%$ Nafion solution, and sonicated for $15 \mathrm{~min}$. The suspension was transferred to the surface of the polished GC disk and dried at $80^{\circ} \mathrm{C}$ for $5 \mathrm{~min}$.

\subsection{Characterization}

Scanning electron microscopy (SEM, Hitachi S-4700) was used to characterize the morphology of the $\mathrm{Fe}_{3} \mathrm{O}_{4}-\mathrm{Fe}_{2} \mathrm{O}_{3}$ nanocomposites. The chemical compositions of the products were detected using an energy-dispersive X-ray spectrometry (EDS, Thermo Noran VANTAG-ESI). The obtained samples were characterized by X-ray powder diffraction (XRD) using a Rigaku D/max- $\gamma \mathrm{B}$ X-ray diffractometer with graphite monochromatized $\mathrm{Cu} \mathrm{K} \alpha$ radiation $(\lambda=1.54178 \AA$ $)$ operated at $40 \mathrm{kV}$ and $80 \mathrm{~mA}$. Electrochemical measurements were performed using a computer-controlled CHI $660 \mathrm{C}$ electrochemical workstation in a standard three-electrode configuration, including $\mathrm{Fe}_{3} \mathrm{O}_{4}-\mathrm{Fe}_{2} \mathrm{O}_{3}$ nanocomposite electrodes as the working electrode, an $\mathrm{Ag} / \mathrm{AgCl}$ reference electrode and a platinum counter electrode. $\mathrm{H}_{2} \mathrm{O}_{2}$ measurement was carried out in $0.01 \mathrm{M}, \mathrm{pH} 7.0$, phosphate buffer containing $0.2-1.8 \mathrm{mM} \mathrm{H}_{2} \mathrm{O}_{2}$.

\section{Results and discussion}

In our study, the calcination temperature is varied from 350 to $450^{\circ} \mathrm{C}$ to investigate its influence on the structure. Figure 1a shows the XRD patterns of the as-obtained products at $350^{\circ} \mathrm{C}$. All the diffraction peaks in figure 1a can be readily indexed to $\mathrm{Fe}_{3} \mathrm{O}_{4}$ of spinel structure (JCPDS Card no. 19-0629). Figure 1b shows the XRD pattern of the asobtained product at $400^{\circ} \mathrm{C}$. All of the peaks of the XRD pattern in figure $1 \mathrm{~b}$ can be indexed to a mixed phase of $\mathrm{Fe}_{3} \mathrm{O}_{4}$ (JCPDS Card no. 19-0629) and $\alpha-\mathrm{Fe}_{2} \mathrm{O}_{3}$ (JCPDS Card no.
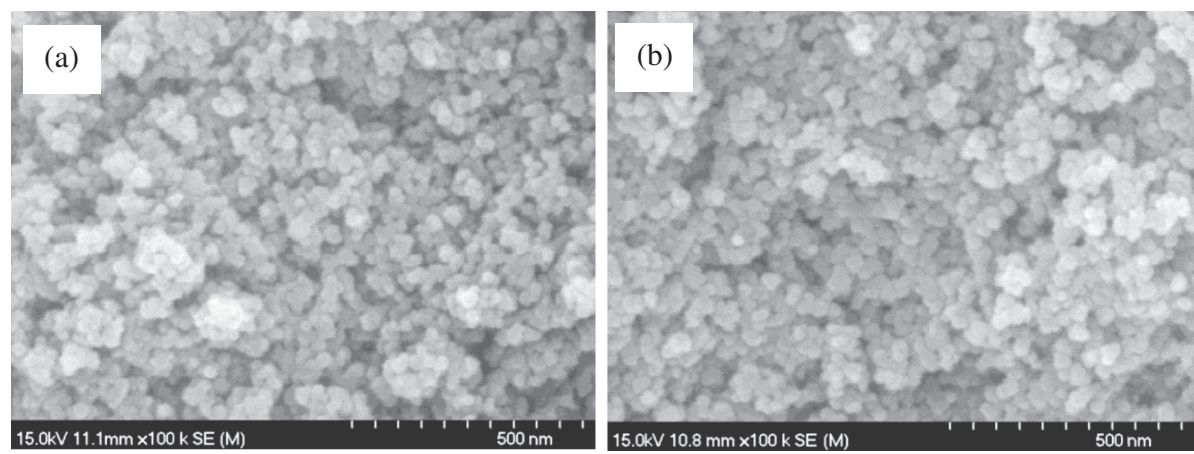

Figure 2. SEM images of the $\mathrm{Fe}_{3} \mathrm{O}_{4}-\mathrm{Fe}_{2} \mathrm{O}_{3}$ nanocomposites prepared at (a) $400^{\circ} \mathrm{C}$ and (b) $450^{\circ} \mathrm{C}$. 
39-1346). This reveals that $\mathrm{Fe}_{3} \mathrm{O}_{4}-\mathrm{Fe}_{2} \mathrm{O}_{3}$ composites were obtained at $400^{\circ} \mathrm{C}$. When calcination temperatures are above $450^{\circ} \mathrm{C}$, it can be easily found from figure $1 \mathrm{c}$ that besides the diffraction peaks of $\mathrm{Fe}_{3} \mathrm{O}_{4}$, strong diffraction peaks of $\alpha-\mathrm{Fe}_{2} \mathrm{O}_{3}$ are observed. Figure 1d shows the XRD patterns of the as-synthesized samples at $500^{\circ} \mathrm{C}$, all the reflection peaks can be readily indexed to $\alpha-\mathrm{Fe}_{2} \mathrm{O}_{3}$ (JCPDS Card no. 391346). The XRD patterns indicate that $\mathrm{Fe}_{3} \mathrm{O}_{4}-\mathrm{Fe}_{2} \mathrm{O}_{3}$ composites were obtained in the calcination temperature range under investigation $\left(350-450^{\circ} \mathrm{C}\right)$.

The morphologies of the as-obtained products were examined by SEM microscopy. Figure 2 a shows the pattern of the $\mathrm{Fe}_{3} \mathrm{O}_{4}-\mathrm{Fe}_{2} \mathrm{O}_{3}$ composites prepared at $400^{\circ} \mathrm{C}$. The SEM image displayed much smaller nanoparticles with diameters of about $40-50 \mathrm{~nm}$. Figure $2 \mathrm{~b}$ is the SEM image of the sample prepared at $450^{\circ} \mathrm{C}$. SEM images revealed that the morphologies of the $\mathrm{Fe}_{3} \mathrm{O}_{4}-\mathrm{Fe}_{2} \mathrm{O}_{3}$ nanocomposites prepared at $450^{\circ} \mathrm{C}$ were similar to the sample prepared at $350^{\circ} \mathrm{C}$.

HRTEM analysis provides more detail structural information about the $\mathrm{Fe}_{3} \mathrm{O}_{4}-\mathrm{Fe}_{2} \mathrm{O}_{3}$ nanocomposites, showing the apparent lattice fringes of the crystal. Figure 3 is an HRTEM image taken from the $\mathrm{Fe}_{3} \mathrm{O}_{4}-\mathrm{Fe}_{2} \mathrm{O}_{3}$ nanocomposites. The observed interplanar spacing is 0.309 and $0.205 \mathrm{~nm}$, which correspond to the (012) atomic spacing of $\mathrm{Fe}_{3} \mathrm{O}_{4}$ and the (400) atomic spacing of $\mathrm{Fe}_{2} \mathrm{O}_{3}$, respectively.

The EDS patterns of the $\mathrm{Fe}_{3} \mathrm{O}_{4}-\mathrm{Fe}_{2} \mathrm{O}_{3}$ nanocomposites prepared at 400 and $450^{\circ} \mathrm{C}$ are shown in figure 4 . It can be seen that the main elements in the samples are $\mathrm{O}$ and $\mathrm{Fe}$ and the peak intensity of $\mathrm{Fe}$ decreases with the increasing calcination temperature. $\mathrm{Fe}$ and $\mathrm{O}$ elements existed in the $\mathrm{Fe}_{3} \mathrm{O}_{4}-$ $\mathrm{Fe}_{2} \mathrm{O}_{3}$ nanocomposites prepared at 400 and $450^{\circ} \mathrm{C}$ have the molar ratio of 72.9:100 and 70.6:100, respectively. By calculation, the $\mathrm{Fe}_{3} \mathrm{O}_{4}-\mathrm{Fe}_{2} \mathrm{O}_{3}$ molar ratios in the $\mathrm{Fe}_{3} \mathrm{O}_{4}-\mathrm{Fe}_{2} \mathrm{O}_{3}$ nanocomposites are 2.22:1 and 0.67:1.

The electrocatalytic activity of the as-obtained products at different calcination temperature was studied. All samples exhibited the reduction of $\mathrm{H}_{2} \mathrm{O}_{2}$ starting around $-0.5 \mathrm{~V}$.

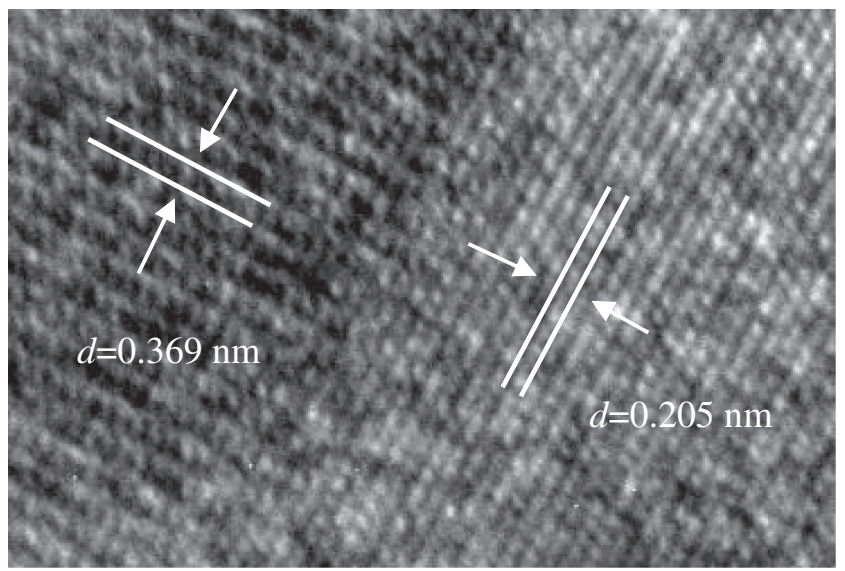

Figure 3. HRTEM images of the $\mathrm{Fe}_{3} \mathrm{O}_{4}-\mathrm{Fe}_{2} \mathrm{O}_{3}$ nanocomposites.
The $\mathrm{Fe}_{3} \mathrm{O}_{4}-\mathrm{Fe}_{2} \mathrm{O}_{3}$ nanocomposites prepared at $400^{\circ} \mathrm{C}$ exhibited the strongest electrocatalytic ability towards the reduction of $\mathrm{H}_{2} \mathrm{O}_{2}$. The electro-reduction mechanism of $\mathrm{H}_{2} \mathrm{O}_{2}$ on
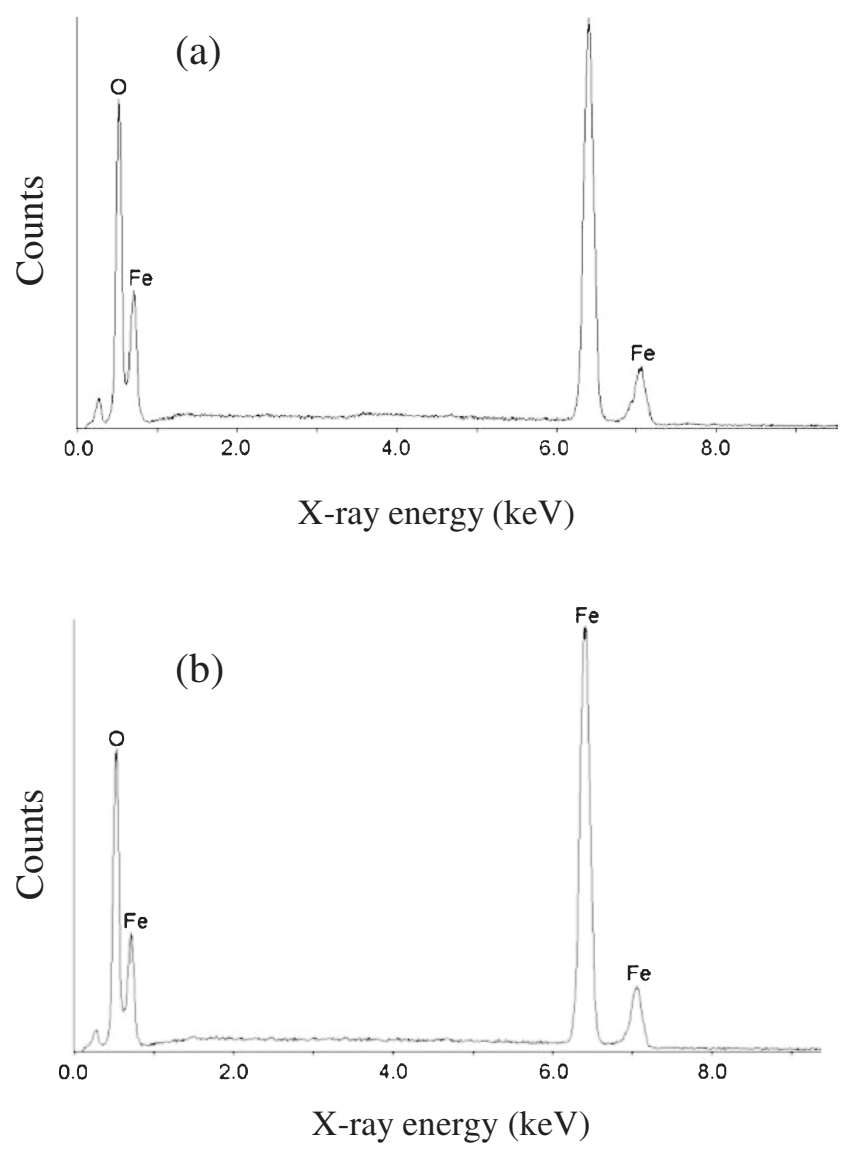

Figure 4. EDS patterns of the $\mathrm{Fe}_{3} \mathrm{O}_{4}-\mathrm{Fe}_{2} \mathrm{O}_{3}$ nanocomposites prepared at (a) $400^{\circ} \mathrm{C}$ and (b) $450^{\circ} \mathrm{C}$.

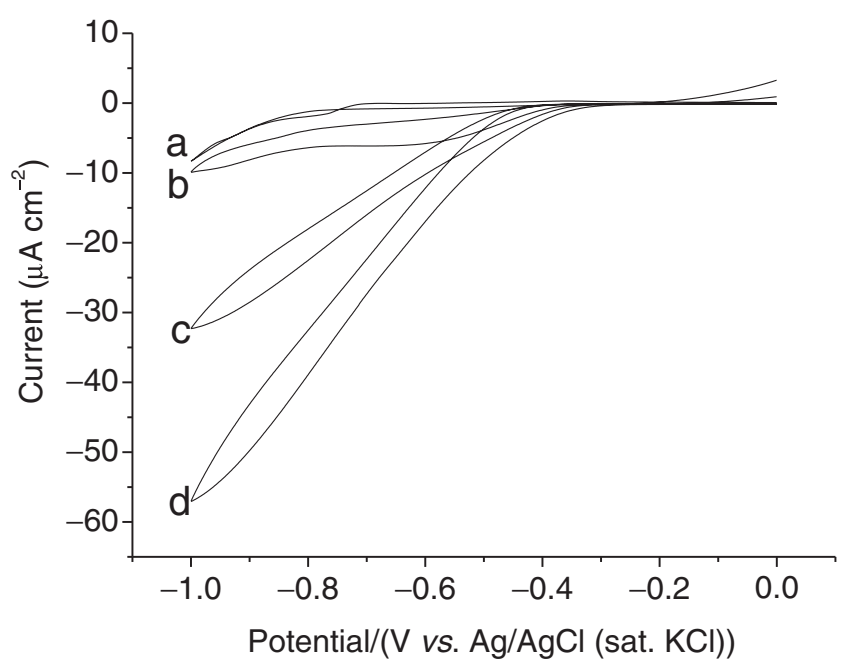

Figure 5. $\mathrm{CV}$ of the $\mathrm{Fe}_{3} \mathrm{O}_{4}-\mathrm{Fe}_{2} \mathrm{O}_{3}$ nanocomposites at various concentrations of $\mathrm{H}_{2} \mathrm{O}_{2}$ : (a) $0 \mathrm{mM}$, (b) $0.2 \mathrm{mM}$, (c) $0.6 \mathrm{mM}$ and (d) $1.0 \mathrm{mM}$. 

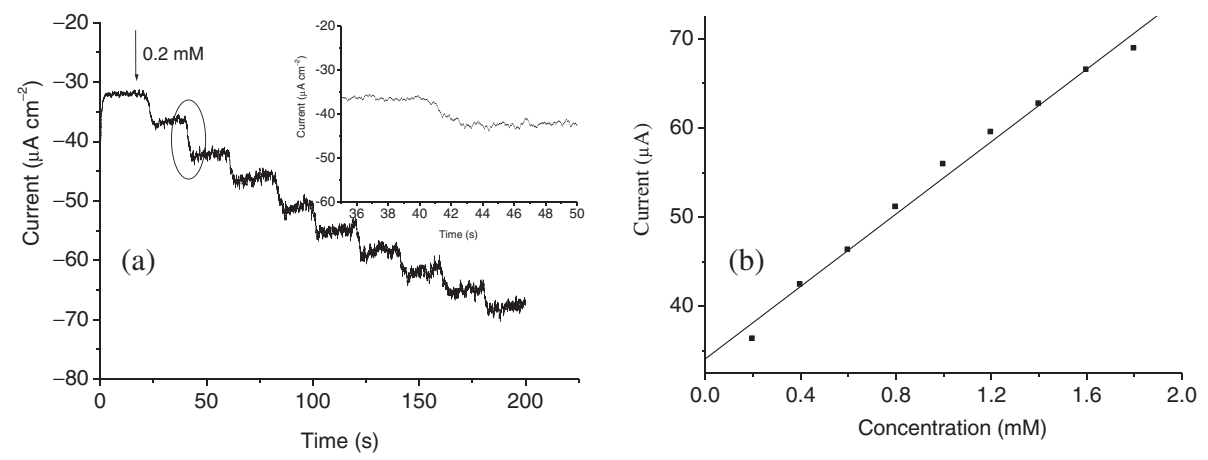

Figure 6. (a) Amperometric current response of the $\mathrm{Fe}_{3} \mathrm{O}_{4}-\mathrm{Fe}_{2} \mathrm{O}_{3}$ nanocomposite electrodes on the successive injection of $\mathrm{H}_{2} \mathrm{O}_{2}$ with various concentrations into stirring $0.01 \mathrm{M}$ phosphate buffer and (b) calibration curve of $\mathrm{H}_{2} \mathrm{O}_{2}$ concentration on the electrode.

the $\mathrm{Fe}_{3} \mathrm{O}_{4}-\mathrm{Fe}_{2} \mathrm{O}_{3}$ nanocomposites can be illustrated by the equations below

$$
\begin{aligned}
& \mathrm{Fe}_{3} \mathrm{O}_{4}+\mathrm{H}_{2} \mathrm{O}_{2} \rightarrow \mathrm{Fe}_{2} \mathrm{O}_{3}+\mathrm{OH}^{-}, \\
& \mathrm{Fe}_{2} \mathrm{O}_{3}+\mathrm{H}_{2} \mathrm{O}+\mathrm{e}^{-} \rightarrow \mathrm{Fe}_{3} \mathrm{O}_{4}+\mathrm{OH}^{-} .
\end{aligned}
$$

Based on the XRD, HRTEM and FDS analysis, it is obvious that the strongest electrocatalytic activity of the $\mathrm{Fe}_{3} \mathrm{O}_{4}-$ $\mathrm{Fe}_{2} \mathrm{O}_{3}$ nanocomposites may be attributed to its structure with the interface of $\mathrm{Fe}_{3} \mathrm{O}_{4}-\mathrm{Fe}_{2} \mathrm{O}_{3}$. According to the mechanism above, the reaction exists in $\mathrm{Fe}_{3} \mathrm{O}_{4}$ and $\mathrm{Fe}_{2} \mathrm{O}_{3}$. In $\mathrm{Fe}_{3} \mathrm{O}_{4}-$ $\mathrm{Fe}_{2} \mathrm{O}_{3}$ nanocomposites, there are many $\mathrm{Fe}_{3} \mathrm{O}_{4}-\mathrm{Fe}_{2} \mathrm{O}_{3}$ interfaces, which is favourable for increasing diffusion rate and accelerating electrode kinetics. It is believed that the structure and $\mathrm{Fe}_{2} \mathrm{O}_{3}$ content have played an important role in controlling the reduction of $\mathrm{H}_{2} \mathrm{O}_{2}$.

Figure 5 shows the $\mathrm{CVs}$ of the $\mathrm{Fe}_{3} \mathrm{O}_{4}-\mathrm{Fe}_{2} \mathrm{O}_{3}$ nanocomposites prepared at $400^{\circ} \mathrm{C}$ in $0.01 \mathrm{M}$ phosphate buffer containing $\mathrm{H}_{2} \mathrm{O}_{2}$ with different concentrations. The current sensitivity increases with increasing $\mathrm{H}_{2} \mathrm{O}_{2}$ concentration (from the top: 0, 0.2, 0.6, $1.0 \mathrm{mM}$ ), which may be applied as the quantitative analysis. Figure 6 a displays a typical current-time plot of the $\mathrm{Fe}_{3} \mathrm{O}_{4}-\mathrm{Fe}_{2} \mathrm{O}_{3}$ nanocomposites on the successive addition of $\mathrm{H}_{2} \mathrm{O}_{2}$ with various concentrations into stirring phosphate buffer $(0.01 \mathrm{M}, \mathrm{pH} 7.0)$ at the applied potential of $-1.0 \mathrm{~V}$. These $\mathrm{Fe}_{3} \mathrm{O}_{4}-\mathrm{Fe}_{2} \mathrm{O}_{3}$ nanocomposite sensors show a very fast response, as the response reaches $100 \%$ of the steady-state value within $2.5 \mathrm{~s}$. The calibration curves of the $\mathrm{Fe}_{3} \mathrm{O}_{4}-\mathrm{Fe}_{2} \mathrm{O}_{3}$ nanocomposites sensor are shown in figure $6 \mathrm{~b}$. The sensor has a wide linear range from 0.2 to $1.8 \mathrm{mM}$ with a correlation coefficient of 0.997 , and the sensitivity is determined to be as $20.325 \mu \mathrm{A} \mathrm{mM}^{-1}$. The selectivity of the sensor was also evaluated with four species: $\mathrm{SO}_{4}{ }^{2-}, \mathrm{Cl}^{-}, \mathrm{ClO}_{3}^{-}$and $\mathrm{CO}_{3}{ }^{2-}$. When $\mathrm{SO}_{4}{ }^{2-}, \mathrm{Cl}^{-}, \mathrm{ClO}_{3}^{-}$and $\mathrm{CO}_{3}^{2-}$ were injected into the phosphate buffer, no obvious current was observed as shown in figure 7 . This suggests that these species have no obvious interference in the reduction of $\mathrm{H}_{2} \mathrm{O}_{2}$.

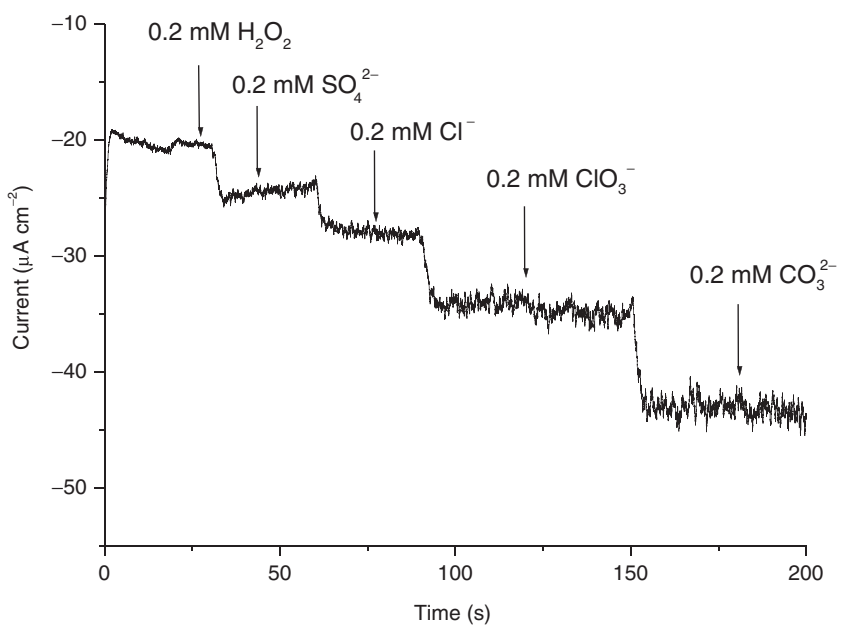

Figure 7. Current responses of the $\mathrm{Fe}_{3} \mathrm{O}_{4}-\mathrm{Fe}_{2} \mathrm{O}_{3}$ nanocomposites to sequential additions of $\mathrm{H}_{2} \mathrm{O}_{2}, \mathrm{SO}_{4}^{2-}, \mathrm{Cl}^{-}, \mathrm{ClO}_{3}^{2-}$ and $\mathrm{CO}_{3}^{2-}$ in $0.01 \mathrm{M}$ phosphate buffer.

\section{Conclusion}

In conclusion, the $\mathrm{Fe}_{3} \mathrm{O}_{4}-\mathrm{Fe}_{2} \mathrm{O}_{3}$ nanocomposites have been successfully synthesized by the co-precipitation method and followed by calcination process. The electrocatalytic activity of the as-obtained products at different calcination temperatures was studied by CV. It was found that the $\mathrm{Fe}_{3} \mathrm{O}_{4}-\mathrm{Fe}_{2} \mathrm{O}_{3}$ nanocomposites obtained at $400^{\circ} \mathrm{C}$ showed maximal electrocatalytic ability for the reduction of $\mathrm{H}_{2} \mathrm{O}_{2}$. The amperometric response of the electrode was rapid (within $2.5 \mathrm{~s}$ ), and had high sensitivity $\left(20.325 \mu \mathrm{A} \mathrm{mM}^{-1}\right)$. The proposed electrochemical sensor based on $\mathrm{Fe}_{3} \mathrm{O}_{4}-\mathrm{Fe}_{2} \mathrm{O}_{3}$ nanocomposites is thus expected to generate new opportunities for monitoring $\mathrm{H}_{2} \mathrm{O}_{2}$ concentrations in industry analyses fields.

\section{References}

1. Klassen N V, Marchington D and Mcgowan H C E 1994 Anal. Chem. 662921 
2. Salimi A, Hallaj R, Soltanian S and Mamkhezri H 2007 Anal. Chim. Acta $\mathbf{5 9 4} 24$

3. Yang Y J and Hu S 2010 Electrochim. Acta 553471

4. Song X C, Wang X, Zheng Y F, Ma R and Yin H Y 2011a J. Nanopart. Res. 131319

5. Diaz A N, Peinado M C R and Minguez M C T 1998 Anal. Chim. Acta 363221

6. Tanner P A and Wong A Y S 1998 Anal. Chim. Acta 370279

7. Cui K, Song Y H, Yao Y, Huang Z Z and Wang L 2008 Electrochem. Commun. 10663

8. Miao X, Yuan R, Chai Y, Shi Y and Yuan Y 2008 J. Electroanal. Chem. $\mathbf{6 1 2} 157$

9. Jia W, Guo M, Zheng Z, Yu T, Rodriguez E G, Wang Y and Lei Y 2009 J. Electroanal. Chem. 62527

10. Gu A, Wang G, Gua J, Zhang X and Fang B 2010 Electrochim. Acta $\mathbf{5 5} 7182$
11. Song X C, Wang X, Zheng Y F, Ma R and Yin H Y 2011b J. Nanopart. Res. 135449

12. Song M, Hwang S W and Whang D 2010 Talanta 801648

13. Tural B, Ozkan N and Volkan M 2009 J. Phys. Chem. Solids 70860

14. Wang N, Zhu L, Wang M, Wang D and Tang H 2010 Ultrasonics Sonochem. 1778

15. Song X C, Zheng Y F and Yin H Y 2013 J. Nanopart. Res. 15 1856

16. Wang Y, Cao J, Yu M, Sun G, Wang X, Bala H and Zhang Z 2013 Mater. Lett. 100102

17. Yu C, Gou L, Zhou X, Bao N and Gu H 2011 Electrochim. Acta 569056

18. Hu Y, Li J, Zhang Z, Zhang H, Luo L and Yao S 2011 Anal. Chim. Acta 69861

19. Shan H, Liu C, Liu L, Li S, Wang L, Zhang X, Bo X and Chi X 2013 Sens. Actuators B 184243 